\title{
Impacts of the global pandemic on the aviation industry of the European Union
}

\author{
Milena Botlíkován ${ }^{1, *}$, Josef Botlík ${ }^{2}$, and Jana Stuchlíková ${ }^{1}$ \\ ${ }^{1}$ Silesian University in Opava, Faculty of Philosophy and Science in Opava, The Institute of \\ Gastronomy, Spa Management and Tourism, Hradecká 17, 74601 Opava, Czechia \\ ${ }^{2}$ Silesian University in Opava, School of Business Administration in Karvina, Department of \\ Informatics and Mathematics, Univerzitní nám. 1934/3, 73340 Karviná, Czechia
}

\begin{abstract}
.
Research background: With the onset of the Covid-19 pandemic, there has been a complete collapse in demand in global markets due to restrictions on movement and market paralysis. Among the sectors most significantly affected is tourism, which is predominantly dependent on the movement of clients. The performance of the tourism industry fell to a minimum during the pandemic. Restaurants and accommodation facilities were closed almost overnight by government intervention. The restriction of free movement has also forced airlines to curb their activities. These companies can be considered as an important globalization element, enabling travel to distant destinations.

Purpose of the article: The article deals with the effects of the pandemic on European Union airlines, as well as the tools adopted to restore air traffic. Based on the analysis, the development of transport flows in air transport before and during the pandemic was evaluated. Furthermore, tools and measures taken to stimulate air services were analyzed and models of possible impacts on the EU aviation industry and selected economic factors were predicted.

Methods: Basic mathematical and statistical methods, correlation analysis, comparisons and predictions were used for the analysis.

Findings \& Value added: The situation brings problems associated with redundancies, i.e. rising unemployment, declining GDP, falling stock markets or airline bankruptcies as in the case of the British Flybe. Based on 2019 data, it can be estimated that in the period March-June 2020, the demand for EU27 passenger air transport decreased by approximately 100 million passengers.
\end{abstract}

Keywords: aviation; Covid-19; tourism; unemployed; European Union

JEL Classification: E69; L83; L93

\footnotetext{
* Corresponding author: milena.botlikova@,fpf.slu.cz
} 


\section{Introduction}

Development of air travel can be considered one of the basic characters of globalization. Air travel is an essential tool for global supply chains [1]. Its significance is in the area of tourism. Air travel allows us to shorten distances and thanks to that we can explore faraway destinations. Similar to other branches air travel is vulnerable to external factors such as petroleum crisis, natural disasters, armed conflicts, terrorist attacks or economic recession [2, 3, and 4]. According to Tadini and Pivo [5] there are direct links between tourism and air travel. Global integration and increased travelling can be considered one of the causes of the pandemic spread. Undoubtedly, we can say that there is a relation between aviation development, tourism and SARS-2 development. For example, in 2003 with the arrival of SARS the demand for air travel has sunk a bit (about $35 \%$ ), similar trend also came in 2008 and 2015 with the occurrence of bird flu. The plane market recovered quite quickly from the mentioned pandemics, with the outbreak of COVID-19 in March 2020, record growth in 2018 and 2019 [2] was replaced by a sharp decline due to macroeconomic and pandemic developments. Literature agrees that one of the most affected branches of the current period is tourism and with it connected air travel. According to IATA, it is one of the biggest crises that the air travel has faced [6]. In Europe, air travel is dependent mostly on the international traffic and it is dominant in the personal transport. According to an estimation of [7], the decline of tourism for the year 2020 will be around $57-61 \%$, due to lacking demand it was expected that by the end of June 2020 the air travel would lose 61 billion dollars total, 35 billion due to cancellation of unrealized flights (ticket return). The whole branch, that is flight companies, airports and providers of flight navigation services had a loss of revenue approximately 110 million euro [8]. Individual estimates can be considered speculative as it depends on the development of the pandemic and decisions of individual governments. In March 2020 European airlines already operated only freight transport especially with medical material, passenger flights were very limited, and flights in March were mainly for a purpose of repatriation. With the stagnation of tourism, the passenger air transport was totally stopped. Many flights were empty for a purpose of upholding position on the flight paths (hold slot). EU conditions suggest that airlines should use $80 \%$ of their capacity to stay competitive [9]. However, in times of air crisis, this system only leads to increased costs and inefficient use of energy resources (unnecessary burning of many thousands of tons of fuel) if we consider that Slovakia, for example, showed zero movement during the pandemic and EU27 air transport fell by about $80 \%$, the EU recommendation cannot be accepted. It can be stated that the pandemic has an unprecedented impact on the aviation branch. There comes a threat of cash position with the following insolvency and threat of millions of job positions being lost immediately in air transport and branches connected to air transport (plane production, ground staff, security service, etc.).

The impacts of pandemic on air transport are very apparent. In current period a flight company FLYBE has ceased activity. For mitigation and effort to eliminate loss, some companies [10] introduced so-called seat maps, which effectively block middle seats in order to retain social distance in the future. These measures contributed to alleviation of social and economic impacts [11]. The duty of the passengers is application of face masks. Some countries of EU-27 require them for the whole flight, other just in check-in areas. The situation is still financially demanding and further unbearable, flight companies appealed for help in a form of loans, grants, other cash options or fee waiver (see Table 1). Governments has focused mainly on development of rescue packages following the COVID-19 situation [12, 13, 14 see Table 1]. Many supports are bound by the assistance with greening of air travel. Many policies link aid to the greening of air transport or participation in corporate governance. German Lufthansa, for example, will have to give up 24 landings and departures 
in Frankfurt am Main and Munich when receiving support. These fiscal measures should eliminate the effects on economic development in general.

Table 1. Support specifically directed to the largest airlines EU-27

\begin{tabular}{|l|l|l|}
\hline & \multicolumn{1}{|c|}{ Support } & \multicolumn{1}{c|}{ Condition of support } \\
\hline Air France & 7 bil. $€$ & Loan guarantees, subsidies, government investments \\
\hline Lufthansa & 9 bil. $€$ & $\begin{array}{l}9 \text { billion rescue package WSF } * 20 \% \text { stake and 2 seats on the } \\
\text { supervisory board, restructuring, surrender of market share }\end{array}$ \\
\hline $\begin{array}{l}\text { Austrian } \\
\text { Airlines** }\end{array}$ & 450 mil. $€$ & $\begin{array}{l}\text { Government investment } € 150 \text { million, loan guarantees } € 300 \\
\text { million }\end{array}$ \\
\hline Conditalia & 550 mil. $€$ & $\begin{array}{l}\text { Loan guarantee (of which } € ~ 256 \text { million is intended for } \\
\text { refinancing a bridging loan from 2019) }\end{array}$ \\
\hline $\begin{array}{l}\text { Norwegian Air } \\
\text { Shuttle }\end{array}$ & 270 mil. $€^{1}$ & $\begin{array}{l}\text { Loan guarantee, conversion of bonds into shares ( 1.1 billion } \\
€)\end{array}$ \\
\hline Airline SAS & 1.7 bil. $€$ & State guarantee \\
\hline Smartwings & $36.8 \mathrm{mil.} €^{1}$ & Credit guarantee, Management share \\
\hline
\end{tabular}

${ }^{1}$ Exchange rate $1 \mathrm{NOK}=0.09 €, 1 \mathrm{CZK}=0.037 €(25.9 .2020),{ }^{*}$ WSF German Economic Stabilization Fund, ** part of the Lufthansa division

\section{Data and methods}

The prediction of passenger air transport development comes from EUROCONTROL data [15], time series $3 \mathrm{M} / 2020$ to $8 \mathrm{M} / 2020$ were analysed. It was about summarization of daily movements on airports in individual countries of EU-27 from the 1st of March 2020 to the 30th of August 2020. Furthermore, the data were compared in relation to development of pandemic, data of the pandemic development came from the University of John Hopkins database [16]. In the first phase, the relationship between the individual quantities was analysed. The most suitable method for the analysis of relationships is correlation analysis, where the bond is expressed by the Spearman coefficient $r(1)$.

If this coefficient reaches a value close to one, it means that there is a strong linear relationship between the individual variables, the punctuation then indicates the position of the linear dependence. Acceptance of the linear relationship hypothesis is conditioned by statistical significance ( $r$ is statistically significant when Sig $(2$-tail) $)<0.05 ; 0.01 ; 0.1)$. Discussion of correlations in more detail in reference [17].

$$
r_{s}=1-\frac{6 \sqrt{\sum d_{i}}}{n\left(n^{2}-1\right)}
$$

where: $d_{i}=\left(x_{i}-y_{i}\right)^{2}, y_{i}, x_{i}$ variables.

The development of the time series of the number of landings and departures for the period 2020 in the EU-27 was carried out using triple exponential balancing, ie balancing using a level 2 dish [17]. This type of prediction is used in the case of short time periods when the trend can be considered constant. Consider that the model of the balanced time series has the form (2), where Tt reflects the trend, in the case of exponential balance the trend has the form (3)

$$
\begin{gathered}
Y_{t}=T_{t}+e_{t} \\
T_{t}=\beta_{0}+\beta_{1} t+\beta_{2} t^{2}
\end{gathered}
$$

The parameters $\beta_{0}, \beta_{1}$ and $\beta_{2}$ are estimated $b_{0}(t), b_{1}(t)$ and $b_{2}(t)$. When estimating at time point $t$, we will proceed from the minimization of expression (4). [17] 


$$
\sum_{j=1}^{\infty}\left(Y_{t-j}-\hat{Y}_{t-j}\right)^{2} \alpha^{j}
$$

where: $\alpha$ represents the compensation constant to which it applies $0<\alpha<1$.

\section{Analysis of the development of EU-27 air transport}

The highest number of arrivals and departures in the EU-27 between March 2020 and August 2020 was recorded on 6 March 2020 (28 051 flights), while the lowest number of flights took place on 12 April 2020 (1 609 flights). On this day, 12 April 2020, compared to 12 April 2019 , there was the largest decrease (-94.6\%) in EU-27 flights. It is obvious that at the time of the loosening of individual measures, there was a gradual recovery of air traffic, see Figure 1 .

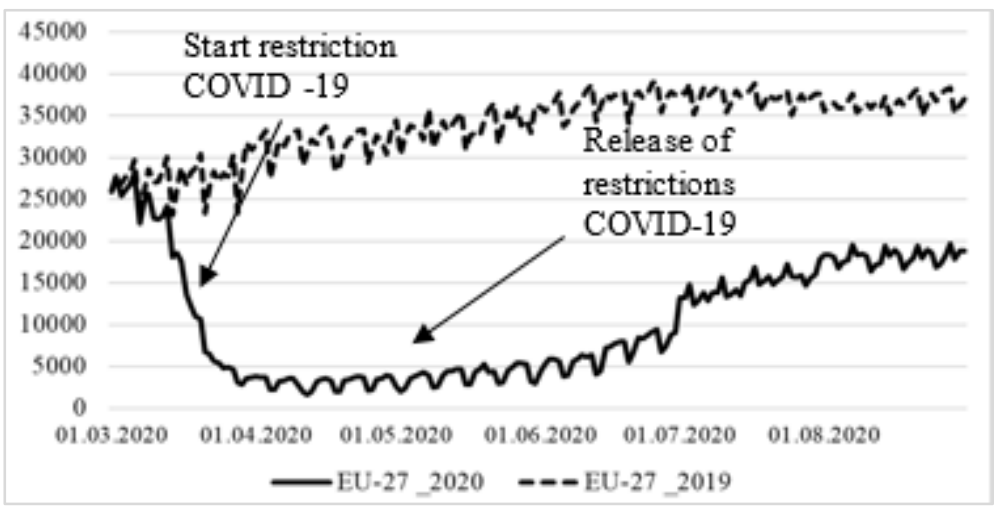

Fig. 1. Development of flights in the EU-27 [15]

The highest year-on-year decrease, calculated as a percentage difference between the sum of flights from March to August 2020 compared to 2020, occurred in Spain (74 \% of landings and departures), Italy (73.1\%) and the Czech Republic (73.9\%). Luxembourg (59.4\%),

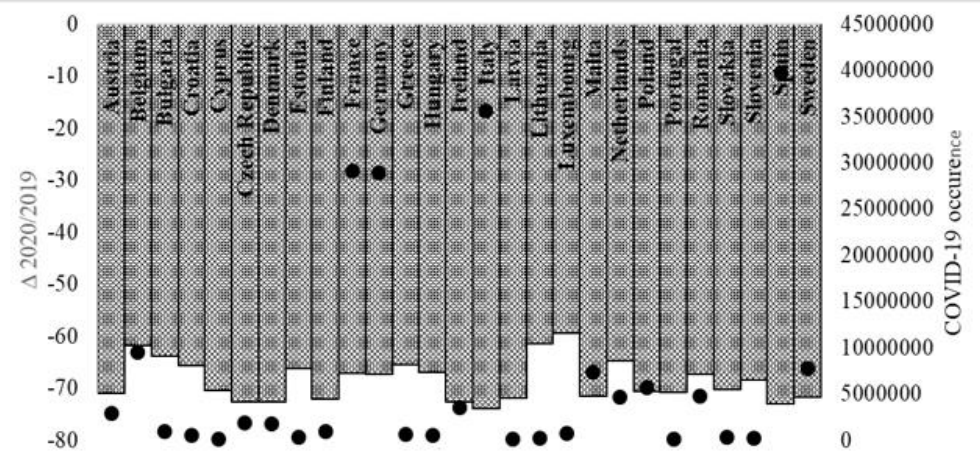

Fig. 2. Development of flights 2020/2019 and occurrence of COVID-19 [15, 16]

Belgium and Lithuania (61.9\% and $61.4 \%$ ) showed the lowest changes during the period considered. In view of the high number of infections in Italy and Spain, the first places in the decline would rightly stop these regions. However, the Czech Republic belonged to a more secure region, despite everything it had the 3-rd highest decline. Therefore, it is not possible to directly search for a link between the incidence of those infected in the EU-27 region and the development of COVID-19. In the case of paralysis of air traffic in individual regions did 
not occur, only Slovakia recorded zero movement for 3 days in the period from March to August (see pracres.eu statistics, Fig. 2).

Correlation analysis was used to verify the above conclusions about the links. From the results of the correlation analysis from the daily values of flights and the development of Covid-19, a very weak linear relationship can be observed between the number of flights and the number of proven COVID-17 and death (correlation coefficient $r_{\text {cov-death } x \text { flights }}=-0.066$; $\left.r_{\text {covid-occurrence } x \text { flights }}=0.069\right)$, which explains that only 6.6 to $6.9 \%$ of the data were not random. Both correlation coefficients were statistically insignificant ( $\mathrm{Sig},>0.05)$, see Table 2. In the case of the COVID variables and the number of flights in 2019, there is a strong positive linear relationship. We can state with some caution that massive travel, which is a characteristic manifestation of globalization (Table 2), may be the cause of the spread of viral disease, which is carried out with a time lag.

Table 1. Correlations analysis in SPSS (daily values)

\begin{tabular}{|l|c|c|c|}
\hline \multirow{2}{*}{$\begin{array}{l}\text { Correlation } \\
(* * \text { Significant at the 0,01) }\end{array}$} & \multicolumn{2}{|c|}{ Daily values } \\
\cline { 3 - 4 } & \multirow{2}{*}{ Flight 2020 } & Covid-occurrence & \multirow{2}{*}{ Covid death } \\
\cline { 3 - 4 } Pearson correlation & & 0.069 & -0.066 \\
\hline Sig 2-tailed & \multirow{2}{*}{ Flight 2019 } & 0.372 & 0.354 \\
\cline { 3 - 4 } Pearson correlation & & $0.869^{* *}$ & $0.886^{* *}$ \\
\hline Sig 2-tailed & & 0.000 & 0.000 \\
\hline
\end{tabular}

The development of flights in the EU-27 was predicted using the software tool MS Excel - function Forecast ETS. ETS function calculates or predicts a future value based on existing (historical) values by using the AAA version of the Exponential Smoothing (ETS) algorithm. Based on the analysis of time series (monthly values), in the case of unchanged conditions, it is possible to assume a return to the number of flights in April 2021, air transport will reach the level of July 2019, according to the pessimistic scenario rather in June 2021.At present, there is no indication of an optimistic scenario, the pandemic is far from over (Figure 3).

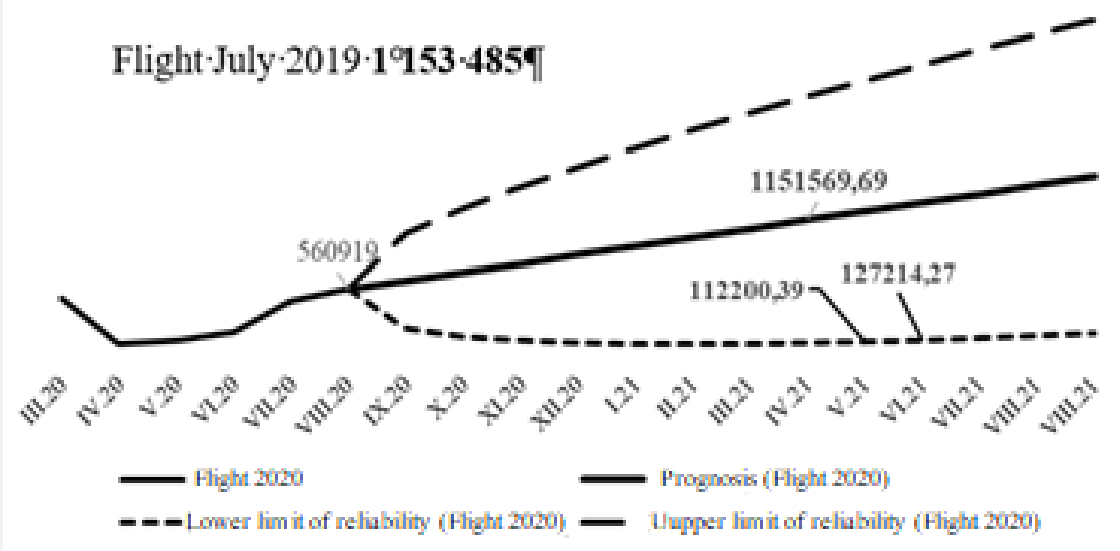

Fig. 3. Flight prediction EU-27 (Excel output). Lower/upper limit of reliability

\section{Discussions and Conclusion}

It is expected that the standardization of air mobility should be achieved within one year, with the number of flights continuing to decrease between $15 \%$ and $25 \%$, based on the projections and expectations [18]. It is clear that the decline in demand during the year was 
largely a reflection of government regulations; the correlation between the daily number of 2020 flights and the development of the pandemic has not been confirmed, which does not mean, however, that there is no independence (it is only not linear). As measures began to loosen, air traffic began to recover slowly. However, globalization can be considered to affect the development of the pandemic (the linear relationship between COVID and 2019).

The length of pandemic in the terms of aviation will be crucial [19]. Due to the time diversity of restriction, the international aviation markets will be renewed slowly, it is likely that national governments will keep travel restriction longer on international flights than domestic flights. Further development of passenger aviation will be significantly affected by the length of the pandemic and to a large extent by consumer trust in the air travel and their economic situation, which will be affected by worries for upcoming economic crisis or the financial exhaustion of potential passengers [20].

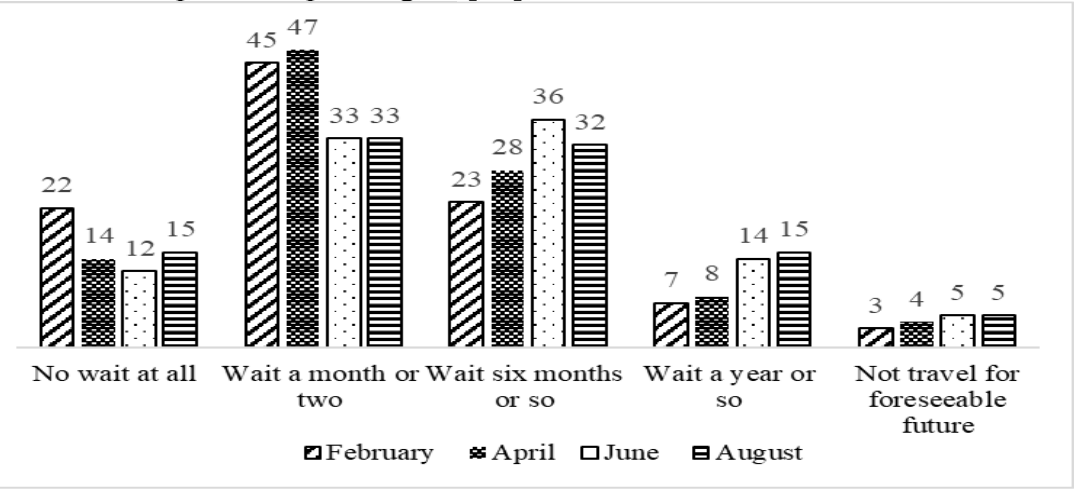

Fig. 4. Willingness to use air transport in the event of a pandemic situation [21]

The slow start of air traffic is also indicated by Survey IATA [21], over $60 \%$ of passengers identify with the current reality and measures taken, i.e. temperature measurement, wearing face masks, the biggest problem of travel is seen by air traffic participants in vicinity of another person, both at check-in and during the flight itself. According to the IATA study [21], based on a credible statement on safe air transport, $47 \%$ of respondents would use air services with an interval of 6 months to a year, but it will depend on the economic situation (approximately $60 \%$ of respondents). Over time, fears of flying tend to increase, the results from August 2020 are rather negative for the development of air transport (see Figure 4).

According to IATA [21], with the onset of the pandemic, 74\% of companies banned international flights. After experience, companies have reconsidered their human resource management strategies and increasingly prefer online meetings. It can thus be assumed that the capacity of demand for conference tourism and business trips will no longer return to the original level before coronavirus. Consumer behaviour is reflected in the development of air transport. It is assumed that air transport will not resume until the following year 2021, from which the prediction of Figure 2 corresponds, but will be $15-25 \%$ below the maximum of 2019 [22]. A certain confidence in flying could be supported by the hypothesis of minimal possibilities of infection in the aircraft [23, 24].

On the other hand, it is possible to agree that the paralysis of air transport has brought about the fulfilment of the strategic goals of sustainable development. Aviation is a major consumer of energy and producer of exhaust fumes. The reduction of air traffic is thus clearly reflected in the reduction of the carbon footprint, the reduction of energy intensity, which is fully correlated with the principles of environmental sustainability [22, 25]. 
The paper was financed from the project Development of R\&D Capacities of the Silesian University in Opava CZ. 02.2.69 / $0.0 / 0.0 / 18 \_054$ / 0014696.

\section{References}

1. Hummels, D. (2012). Moving Boxes by Air: The Economics of International Air Cargo. Journal of Economic Literature, 50(3), 807-809.

2. Suau-Sanchez, P., Voltes-Dorta, A., Cugueró-Escofetad, N. (2020). An early assessment of the impact of COVID-19 on air transport: Just another crisis or the end of aviation as we know it? Journal of Transport Geography, 86, 102749.

3. Kostková, M., Pellešová, P. (2017). The Incoming Changesof the Russian Tourists to the Czech Republic. In V. Klímová \& V. Žitek (Eds.), Procceding 20th International Colloquium on Regional Sciences 2017 Conference (pp. 652-659). Brno: Masarykova univerzita Brno.

4. Šenkova, A. (2010). Economic Crisis and Tourism Development in SlovakiaIn R. Stefko, M. Frankovsky \& P. Adamisin (Eds.), Procceding cientific Conference on Management - Knowledge and Management in Times of Crisis and Ensuing Development 2010 Conference (pp. 652-659). Prešov: Univ Prešov.

5. Tadini, M., Piva, E. (2020). The impact of Covid-19 on air transport and tourism: possible evolving scenarios. Documenti Geografici, 1, 565-578.

6. Looming Cash Crisis Threatens Airlines (2020, October 6). IATA. Retrieved from : https://www.iata.org/en/pressroom/pr/2020-10-06-01/

7. Effects of Novel Coronavirus (COVID-19) on Civil Aviation: Economic Impact Analysis. (2020, November 18). ICAO Uniting Aviation. Retrieved from : https://www.icao.int/sustainability/Documents/COVID-19/ICAO_Coronavirus_Econ Impact.pdf

8. Aviation recovery - Importance of a coordinated approach. (2020, April 27). Eurocontrol. Retrieved from: http://www.eurocontrol.int/sites/default/files/2 020-04/eurocontrol-aviation-recovery-factsheet-27042020.pdf.

9. Zpráva komise Evropskému parlamentu a Radě. (2020, November 14). EURO- LEX Europa. Retrieved from: https://ec.europa.eu/transparency/regdoc/rep/1/2 020/CS/COM-2020-558-F1-CS-MAIN-PART-1.PDF

10. Freed, J. (2020, May 19). Australia's Qantas set to ramp up domestic flights without social distancing. NASDAQ. Retrieved from: https://www.nasdaq.com/articles/australi as-qantas-set-to-ramp-up-domestic-flights-without-social-distancing-2020-05-18

11. Carulla, S. R. (2020). Covid-19 and Air Transport (February 9 - April 30, 2020). Revista General De Derecho Administrativo, 58, 422484.

12. Valná hromada Lufthansy schválila vládní záchranný balik. (2020, Juny 25). Fxstreet. Retrieved from : https://www.fxstreet.cz/zpravodajstvi-111664.html

13. Německo půjči aerolinkám Condor $v$ přepočtu 10 miliard na zajištěni provozu. (2019, September 25). Zpravodajství Idnes. Retrieved from : https://www.idnes.cz/ekonomika/zahranicni/thomas-cook-krach-cestovni-kancelarpujcka-uver-nemecko.A190925_093800_eko-zahranicni_jadv

14. Norwegian Air dostanou státní garance, firmu vlastní věřitelé. (2020, May 20). Investiční web. Retrieved from : https://www.investicniweb.cz/news-norwegian-airdostanou-statni-garance-firmu-vlastni-veritele/ 
15. Daily Traffic Variation - States. (2020). Eurocontrol. Retrieved from : https://www.eurocontrol.int/Economics/DailyTrafficVariation-States.html

16. Kropáček, J. (2020, March 13). Koronavirus na mapě světa: Kde je nejvíc nemocných a jak se nákaza šiř́i. Aktuálně. Retrieved from

: https://zpravy.aktualne.cz/zahranici/koronavirus- na- mape- sveta- kde- je- nejvic- ne mocnych- a- jak- se- n/r 80b98b4e6cde11 ea9d470cc47ab5f122/

17. Tošenovský, F. (2014). Statistické metody pro ekonomy. Karviná: Faculty of Business Administration in Opava.

18. Truxal, S. (2020). State Aid and Air Transport in the Shadow of COVID-19. Air \& Space Law, 45(SI), 61-82.

19. Janczuk, M., Czapski, G. (2020). The Impact of the Coronavirus Epidemic on Air Transport in Poland. Postmodern Openings, 11(2), 66-72.

20. Slow Recovery Needs Confidence Boosting Measures (2020, April 21). IATA. Retrieved from : https://www.iata.org/en/pressroom/pr/2020-04-21-01/

21. COVID-19 Report Content - Passenger Survey, Issue 1-3: Passenger insights in the times of a pandemic. (2020). IATA. Retrieved from

: https://www.iata.org/en/publications/store/covid-passenger-survey/

22. Nižetić, S. (2020). Impact of coronavirus (COVID-19) pandemic on air transport mobility, energy, and environment: A case study. International Journal of Energy Research, (SI), 1-9.

23. Hardingham-Gill, T. (2020, August 20). The odds of catching Covid-19 on an airplane are slimmer than you think, scientists say. CNN Travel. Retrieved from : https://edition.cnn.com/travel/article/odds-catching-covid-19-flight-wellnessscn/index.html

24. Abu-Rayash, A., Dincer, I. (2020). Analysis of mobility trends during the COVID-19 coronavirus pandemic: Exploring the impacts on global aviation and travel in selected cities. Energy research \& social science, 68, 101693.

25. Yang, N., et al. (2020). In-flight transmission cluster of COVID-19: A retrospective case series. Infectious Diseases, 52(12), 891-901. 